\title{
Nitrogen Fertilizer Equivalence of Black Soldier Fly Frass Fertilizer and Synchrony of Nitrogen Mineralization for Maize Production
}

\author{
Dennis Beesigamukama ${ }^{1,2,3}{ }^{(\mathbb{D}}$, Benson Mochoge ${ }^{2}$, Nicholas Korir ${ }^{2}$, Martha W. Musyoka ${ }^{1}{ }^{1}$, \\ Komi K. M. Fiaboe ${ }^{1,4}{ }^{(\mathbb{C}}$, Dorothy Nakimbugwe ${ }^{5}$, Fathiya M. Khamis ${ }^{1}$, Sevgan Subramanian ${ }^{1}{ }^{10}$, \\ Thomas Dubois ${ }^{1} \mathbb{D}$, Sunday Ekesi ${ }^{1}$ and Chrysantus M. Tanga ${ }^{1, *(1)}$ \\ 1 International Centre of Insect Physiology and Ecology, P.O. Box 30772-00100 Nairobi, Kenya; \\ dbeesigamukama@icipe.org (D.B.); mmusyoka@icipe.org (M.W.M.); K.Fiaboe@cgiar.org (K.K.M.F.); \\ fkhamis@icipe.org (F.M.K.); ssubramania@icipe.org (S.S.); tdubois@icipe.org (T.D.); sekesi@icipe.org (S.E.) \\ 2 Department of Agricultural Science and Technology, Kenyatta University, \\ P.O. Box 43844-00100 Nairobi, Kenya; bensonmochoge@gmail.com (B.M.); korir.nicholas@ku.ac.ke (N.K.) \\ 3 Department of Crop Production and Management, Busitema University, P.O. Box 236 Tororo, Uganda \\ 4 International Institute of Tropical Agriculture, B.P. 2008 (Messa), Nkolbisson, Yaoundé, Cameroon \\ 5 Department of Food Technology and Nutrition, School of Food Technology, Nutrition \& Bioengineering, \\ Makerere University, P.O. Box 7062 Kampala, Uganda; dnakimbugwe@gmail.com \\ * Correspondence: ctanga@icipe.org; Tel.: +254-702729931
}

Received: 6 August 2020; Accepted: 4 September 2020; Published: 15 September 2020

check for updates

\begin{abstract}
The use of black soldier fly frass fertilizer (BSFFF) is being promoted globally. However, information on nitrogen (N) fertilizer equivalence (NFE) value and synchrony of $\mathrm{N}$ mineralization for crop production remains largely unknown. Comparative studies between BSFFF and commercial organic fertilizer (SAFI) were undertaken under field conditions to determine synchrony of $\mathrm{N}$ release for maize uptake. The BSFFF, SAFI, and urea fertilizers were applied at the rates of $0,30,60$, and $100 \mathrm{~kg} \mathrm{~N} \mathrm{ha}^{-1}$. The yield data from urea treated plots were used to determine the NFE of both organic inputs. Results showed that maize from BSFFF treated plots had higher $\mathrm{N}$ uptake than that from SAFI treated plots. High $\mathrm{N}$ immobilization was observed throughout the active growth stages of maize grown in soil amended with BSFFF, whereas soil treated with SAFI achieved net N release at the silking stage. Up to three times higher negative $\mathrm{N}$ fluxes were observed in SAFI amended soils as compared with BSFFF treated plots at the tasseling stage. The BSFFF applied at 30 and $60 \mathrm{~kg} \mathrm{~N} \mathrm{ha}^{-1}$ achieved significantly higher NFE than all SAFI treatments. Our findings revealed that BSFFF is a promising and sustainable alternative to SAFI or urea for enhanced maize production.
\end{abstract}

Keywords: frass fertilizer; Hermertia illucens; maize; nitrogen fertilizer equivalence; nitrogen mineralization; nitrogen synchrony

\section{Introduction}

Organic fertilizer inputs are one of the promising pathways for sustainably improving soil and crop productivity [1,2]. These organic fertilizers are a good source of nitrogen, which is one of the most limiting soil nutrients for crop production in most parts of sub-Saharan Africa (SSA) [3,4]. Organic fertilizers are an ingredient of stable soil aggregates and are known for improving soil $\mathrm{pH}$, soil organic matter, levels of secondary and micronutrients $[2,5-8]$, as well as nutrient availability, uptake, and utilization $[9,10]$.

Farming systems in countries of SSA rely mostly on inherent soil fertility with very little inputs of mineral fertilizers because of their high costs and unavailability from a local source [11]. Likewise, 
the use of organic manures is still limited largely because of their low availability due to other competing uses on the farm such as feeding of animals [12,13] and domestic use as fuel [14]. Such competing uses leave little or none of the organic resources for use in crop production. Therefore, improving soil productivity using organic resources requires a venture into new organic fertilizer sources.

An increasing demand for animal feed through insect mass rearing using organic substrates $[15,16]$ presents an opportunity for recycling organic wastes into organic fertilizer for soil fertility management. The black soldier fly (Hermetia illucens L.) (BSF) larvae are reared on organic wastes which produce a nutrient-rich frass [17-19]. The high waste degradation efficiency (66-79\%) [20] of BSF larvae and their ability to significantly reduce pathogens present in waste [17] make them efficient organic cyclers that could also benefit soil fertility. Converting BSF frass into organic fertilizer would be a fast and efficient way of recycling nutrients present in organic wastes for soil fertility improvement.

The effectiveness of organic fertilizers for crop production largely depends on their nutrient content, especially nitrogen $(\mathrm{N})$, and rate of nutrient release [21-23]. Plant available $\mathrm{N}$ from organic fertilizers is highly dependent on their composition, organic $\mathrm{N}$ fractions, $\mathrm{C} / \mathrm{N}$ ratio, appropriate timing, rate, and method of application [24,25]. Nitrogen mineralization rate is the single most important factor which determines the quantity and period in which nutrients from organic fertilizers are available for plant uptake [21,23]. For optimal crop growth and yield, $\mathrm{N}$ mineralization patterns should match fluctuations in crop nutrient demands to cause synchrony, i.e., the balance between $\mathrm{N}$ supply and $\mathrm{N}$ demand [26].

Although the mineralization and synchrony of $\mathrm{N}$ from different organic resources have been widely studied [22-24,27], information on BSF frass fertilizer (BSFFF) is unknown since it is a relatively new organic fertilizer product. However, a similar study was done by Adin Yéton et al. [28] who used a litter bag experiment which did not incorporate the frass into the soil, thereby ignoring the soil factors that influence $\mathrm{N}$ mineralization $[25,29,30]$. At the same time, this experiment did not involve a crop, thus making it difficult to know whether the $\mathrm{N}$ mineralized from BSFFF could match the crop $\mathrm{N}$ demand, because, although the $\mathrm{N}$ content of the organic fertilizer could be high, its release could be hampered by soil factors such as $\mathrm{pH}$, bacterial regime, and $\mathrm{C} / \mathrm{N}$ ratio of the substrate after incorporation in the soil $[23,26]$.

While using organic fertilizers, the likelihood of meeting crop $\mathrm{N}$ demand during critical growth stages depends on the ability of the crop to compete for the mineralized $\mathrm{N}$ with other consumption pathways such as immobilization by microbes [30], losses through volatilization, and leaching beyond the rooting system. Information on the dynamics and synchrony of N release from BSFFF for crop production in any cropping system is unknown. However, such information would guide recommendations on timing and rate of application for BSFFF for efficient $\mathrm{N}$ management.

The quality of an organic resource is also assessed based on its performance as compared with a standard mineral fertilizer, also known as the $\mathrm{N}$ fertilizer equivalence (NFE) [22,31]. Nitrogen fertilizer equivalence also known as nitrogen fertilizer replacement value, is the amount of mineral fertilizer $\mathrm{N}$ saved when using organic amendment to produce the same yield [32]. Nitrogen fertilizer equivalences of organic resources have been found to vary with the sources [33] and application rates [32]. In real terms, this means that there is a rate at which organic fertilizers can achieve similar yields as mineral fertilizer. Unfortunately, the NFE of BSFFF is not known, although it would guide optimum application rates for efficient $\mathrm{N}$ management. Such information would also act as a basis for integrating BSFFF into existing cropping practices. To address these knowledge gaps, comparative studies were carried out to determine the NFE, $\mathrm{N}$ release, $\mathrm{N}$ uptake, and synchrony of $\mathrm{N}$ released from soils amended with BSFFF, and existing commonly used commercial organic fertilizer for maize production. 


\section{Materials and Methods}

\subsection{Site Characteristics}

Field experiments were set up for two seasons (April-September 2019 (short rains) and October 2019-March 2020 (long rains)) at the Kenyatta University teaching and demonstration farm (1'10'59" S, 36 55'34" E, $1580 \mathrm{~m}$ above sea level), Nairobi County, Kenya. The area receives bimodal rainfall with annual averages of $925 \mathrm{~mm}$. The first rainfall season starts from March to June, while the second season runs from October to December. The mean monthly temperatures of the area range between 21 and $28{ }^{\circ} \mathrm{C}$ [34]. During the period of experiments, the average monthly temperatures ranged between 25 and $27^{\circ} \mathrm{C}$, with the highest values recorded during the short rain season (FS 1). The long rain season received relatively higher mean monthly rainfall (31-102 $\mathrm{mm})$ than the short rain season (40-87 $\mathrm{mm})$.

Soils in the study site are acric ferralsols [35] characterized by low organic matter, shallow depths, and low $\mathrm{pH}$ levels. Before the experiments, soils were sampled $(0-20 \mathrm{~cm})$ for determination of total organic $\mathrm{N}$, total organic carbon, available phosphorus $(\mathrm{P})$, exchangeable cations (potassium $(\mathrm{K})$, calcium (Ca), and magnesium $(\mathrm{Mg}), \mathrm{pH}$, electrical conductivity, and soil texture using procedures described by Okalebo et al. [36]. Table 1 shows selected physical and chemical characteristics of the soils used in the experiment. Soil moisture content at different stages of crop growth in the topsoil $(0-20 \mathrm{~cm})$ (Figure 1a,b) and subsoil $(20-40 \mathrm{~cm}$ ) (Figure 1c,d) was also monitored during the experimental period.
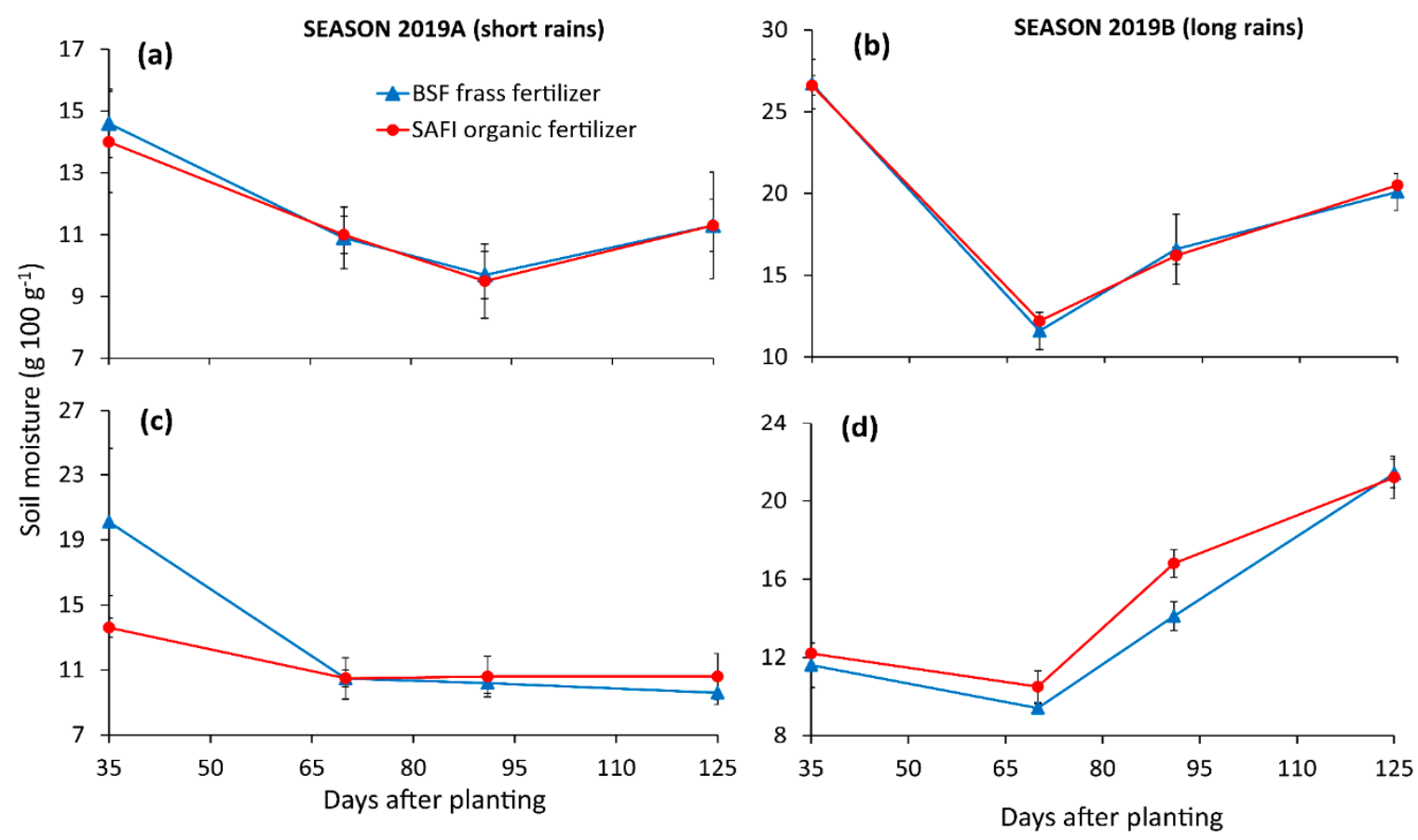

Figure 1. Soil moisture content in the topsoil $(0-20 \mathrm{~cm})(\mathbf{a}, \mathbf{b})$ and subsoil $(20-40 \mathrm{~cm})(\mathbf{c}, \mathbf{d})$, during the short and long rain season experiments. 
Table 1. Selected physical and chemical characteristics of the experimental soil, and organic fertilizers.

\begin{tabular}{|c|c|c|c|c|c|c|c|c|c|c|c|c|c|c|}
\hline \multicolumn{15}{|c|}{ Experimental Soil } \\
\hline \multirow{2}{*}{ Parameter } & \multirow{2}{*}{$\begin{array}{c}\mathrm{pH} \\
(1: 2.5 \text { water })\end{array}$} & \multirow{2}{*}{$\frac{\text { Bulk density }}{\left(\mathrm{g} \mathrm{cm}^{-3}\right)}$} & \multirow{2}{*}{$\begin{array}{l}\text { Mineral N } \\
\left(\mathrm{mg} \mathrm{kg}^{-1}\right)\end{array}$} & \multirow[t]{2}{*}{ Total N } & \multirow{2}{*}{$\frac{\text { TOC }}{(\%)}$} & \multirow[t]{2}{*}{$\mathrm{SOM}$} & \multirow{2}{*}{$\begin{array}{l}\text { Available } \\
\text { P (ppm) }\end{array}$} & \multicolumn{3}{|c|}{$\begin{array}{l}\text { Exchangeable cations } \\
\left(\mathrm{cmol} \mathrm{kg}^{-1}\right)\end{array}$} & \multirow[t]{2}{*}{ Sand } & \multirow{2}{*}{$\begin{array}{l}\text { Clay } \\
(\%)\end{array}$} & \multirow[t]{2}{*}{ Silt } & \multirow[t]{2}{*}{ Textural class } \\
\hline & & & & & & & & $\mathrm{K}$ & $\mathrm{Ca}$ & $\mathrm{Mg}$ & & & & \\
\hline Test value & 5.9 & 1.35 & 1.81 & 0.04 & 1.3 & 2.3 & 9.7 & 2.07 & 0.91 & 0.07 & 63 & 20.3 & 16.7 & Sandy loam \\
\hline \multicolumn{15}{|c|}{ Organic Fertilizers } \\
\hline \multirow{2}{*}{ Parameters } & \multirow{2}{*}{ Moisture (\%) } & \multirow{2}{*}{$\mathrm{pH}$} & \multirow{2}{*}{$\begin{array}{c}\mathrm{EC} \\
\left(\mathrm{mS} \mathrm{cm}^{-1}\right)\end{array}$} & Ammor & ium & Nitrate & TOC & Total N & Total P & Total K & Total Ca & & $\mathrm{Mg}$ & $\mathrm{C} / \mathrm{N}$ ratio \\
\hline & & & & \multicolumn{3}{|c|}{$\left(\mathrm{mg} \mathrm{kg}^{-1}\right)$} & \multicolumn{8}{|c|}{$(\%)$} \\
\hline BSFFF & 30.1 & 7.7 & 2.7 & \multicolumn{2}{|c|}{74.4} & 1.39 & 35.2 & 2.1 & 1.16 & 0.17 & 0.19 & \multicolumn{2}{|c|}{0.16} & 16.8 \\
\hline SAFI & 29.8 & 6.4 & 6.1 & \multicolumn{2}{|c|}{39.4} & 92.3 & 45.1 & 3.0 & 1.23 & 1.49 & 0.29 & \multicolumn{2}{|c|}{0.43} & 15.0 \\
\hline
\end{tabular}

Key: TOC total organic carbon; SOM, soil organic matter; EC, electrical conductivity; BSFFF, black soldier fly frass fertilizer; SAFI, commercial organic fertilizer. 


\subsection{Experiment 1: Nitrogen Fertilizer Equivalence Values of Black Soldier Fly Frass Fertilizer (BSFFF)} and Commercial Organic Fertilizer (SAFI)

\subsubsection{Source of Organic Fertilizers}

The experiment involved the following three fertilizers: two organic fertilizers (BSFFF and commercial organic fertilizer (SAFI)) and one inorganic $\mathrm{N}$ fertilizer (urea, $45 \% \mathrm{~N}$ ). The BSFFF was a product obtained from the feeding of BSF larvae on brewery spent grain (sourced from Kenya Breweries Limited, Nairobi, Kenya) at the animal rearing and quarantine unit of the International Centre of Insect Physiology and Ecology (icipe), Nairobi. The BSF larvae were reared in metallic trays, as described by Shumo et al. [37], using a rearing substrate that was hydrated to approximately $70 \pm 1 \%$ moisture content. The rearing facility of BSF larvae was equipped with wooden stands (180 cm high $\times 66 \mathrm{~cm}$ wide $\times 420 \mathrm{~cm}$ long). Each wooden stand had three shelves separated from each other by a $30 \mathrm{~cm}$ space, where the metallic trays used in rearing the BSF larvae were fitted. Metallic trays used during the experiment measured $76 \mathrm{~cm}$ long, $27.5 \mathrm{~cm}$ wide, and $10 \mathrm{~cm}$ deep. The bottom of each tray measured $52 \mathrm{~cm}$ in length by $27.5 \mathrm{~cm}$ width, which allowed for both edges of the tray to be inclined at an angle of $35^{\circ}$.

The experimental room was heated using fast moving dry hot air at $28.0 \pm 2{ }^{\circ} \mathrm{C}$ (using an Xpelair heater, Wall Fan Heater, Peterborough, United Kingdom) with thermoregulators. Portable digital thermo-hygrometers were placed inside each of the rearing rooms to monitor temperature and relative humidity. Conditions in the experimental rearing room were maintained at $28 \pm 2{ }^{\circ} \mathrm{C}, 60-70 \%$ relative humidity, and a photoperiod of L12:D12. After 2 weeks, the larvae were harvested by sieving to separate them from the frass. The frass obtained was composted inside a greenhouse using the heap method. During composting, frass heaps of $1 \mathrm{~m}$ height and $4 \mathrm{~m}$ long were built on surfaces lined with polythene sheets and hydrated to a moisture content of $55-65 \%$. The heaps were covered using polythene sheets (1000 $\mathrm{mm}$ gauge) to prevent moisture and heat loss. The composting materials were turned on a weekly basis using a forked spade to ensure uniform decomposition. Compost maturity was monitored on a weekly basis using the $\mathrm{C} / \mathrm{N}$ ratio, $\mathrm{pH}$, and electrical conductivity. After five weeks, a mature and stable frass product was obtained and used in the experiments as BSFFF.

The commercial organic fertilizer (SAFI) was sourced from Safi organics limited [38] located in Mwea town, Kirinyaga County, Kenya. It was made from composted chicken manure, biochar, and rock phosphate. Urea fertilizer was sourced from the Kenya farmers' association stores, Nairobi. Table 1 shows selected physical-chemical characteristics of the organic fertilizers used in the experiments.

\subsubsection{Experimental Design and Data Collection}

The three fertilizers were applied at three rates each, equivalent to 30,60 , and $100 \mathrm{~kg} \mathrm{~N} \mathrm{ha}^{-1}$. These were denoted as 30N BSFFF, 60N BSFFF, and 100N BSFFF for BSFFF treatments; 30N SAFI, 60N SAFI, and 100N SAFI for SAFI organic fertilizer treatments; and 30N UREA, 60N UREA, and 100N UREA for urea treatments. The control treatment was not amended. To avoid any nutrient limitations that could hinder crop response to the applied N, inorganic $\mathrm{P}$ (supplied as triple super phosphate (TSP), $46 \% \mathrm{P}_{2} \mathrm{O}_{5}$ ) and $\mathrm{K}$ (supplied as muriate of potash, $60 \% \mathrm{~K}_{2} \mathrm{O}$ ) were applied at blanket rates of $60 \mathrm{~kg} \mathrm{P} \mathrm{ha}^{-1}$ and $50 \mathrm{~kg} \mathrm{~K} \mathrm{ha}^{-1}$ [39]. For SAFI and BSFFF treatments, inorganic $\mathrm{P}$ and $\mathrm{K}$ were applied after considering the quantities (of $\mathrm{P}$ and $\mathrm{K}$ ) contained in the dry matter used to supply the different levels of $\mathrm{N}$.

The maize variety H513 (Kenya seed company, Nairobi, Kenya), which is recommended for low and medium altitude areas of Kenya, was used as the test crop. The experiments were set out as a randomized complete block design with split-plot treatment structure and three replicates. Fertilizer types were the main plot factors, whereas $\mathrm{N}$ rates were the subplot factors. Plots measured $4 \times 4 \mathrm{~m}$ with border widths of $0.5 \mathrm{~m}$ and $1 \mathrm{~m}$ for the plots and blocks, respectively. The TSP fertilizer was applied at planting, whereas urea and muriate of potash were applied in two splits, i.e., $50 \%$ at 4 weeks after planting and another $50 \%$ at 7 weeks after planting. The standard crop husbandry procedures were carried out during the experiment. 
At harvesting, yield data were collected per plot after all the ears had dried. Plants in each plot were cut at ground level, their ears threshed to determine grain weights and weight of residues using a weighing scale. Grain and stover samples were taken to the laboratory and air-dried to $12.5 \%$ moisture content for determination of grain and stover yields per treatment and calculated on a hectare basis $\left(\mathrm{tha}^{-1}\right)$.

Grain yields from the urea fertilizer treatment were used to draw the $\mathrm{N}$ response curve that was used to calculate the N fertilizer equivalence (NFE) values of the two organic fertilizers (Equation (1)) [31]. For easy comparison between treatments, the NFE values were converted into percentages [40,41].

$$
\operatorname{NFE}\left(\mathrm{kg} \mathrm{kg}^{-1}\right)=\frac{N A_{f=G Y}}{N A_{\text {org }}}
$$

where $N A_{f=G Y}$ represents the mineral fertilizer, $N$, required to obtain grain yield equivalent to those of organic fertilizer treatments $\left(\mathrm{kg} \mathrm{ha}^{-1}\right)$. The $N A_{f=G Y}$ for each organic fertilizer treatment was estimated using the grain yield response curve specific to each season. $N A_{\text {org }}$ represents the total $N$ supplied by organic fertilizer inputs.

\subsection{Experiment 2: Nitrogen Mineralization and Synchrony of N Release for Maize Uptake}

The BSFFF and SAFI organic fertilizers were applied at rates of 0 and $5 \mathrm{tha}^{-1}$, an organic fertilizer rate that has been previously used in central Kenya [23,42,43]. Maize (H513 variety) was used as the test crop. The experiments were set out as randomized complete block design with three replicates, and for two seasons (April to September 2019 and October to March 2020). The plot dimensions were like those described in Experiment 1. Table 2 shows characteristics of the soil alone and amended soils at the start of the long rain season experiments (October 2019).

The experiments were managed according to standard agronomic practices. Data on biomass amounts and nitrogen uptake were determined at the early vegetative stage (35 days after planting, DAP) at tasseling (70 DAP), at silking (91 DAP), and at maturity (harvesting) (125 DAP) stages. Two plants were randomly selected from each plot, cut at ground level, and their fresh weights determined. Thereafter, their subsamples were oven dried at $60{ }^{\circ} \mathrm{C}$ for $72 \mathrm{~h}$, cooled, and the dry weights determined. The dried samples were ground into powder which was used for the determination of total $\mathrm{N}$ and $\mathrm{N}$ uptake (Equation (2)):

$$
N \operatorname{uptake}\left(\mathrm{kg} \mathrm{ha}^{-1}\right)=\frac{\% \mathrm{~N} \times \operatorname{dry} \operatorname{matter}\left(\mathrm{kg} \mathrm{ha}^{-1}\right)}{100}
$$

Grain and stover yield data were collected at the harvesting stage from a net plot area of $9 \mathrm{~m}^{2}$ which was calculated on a hectare basis $\left(\mathrm{t} \mathrm{ha}^{-1}\right)$, as described in Experiment 1 above. Part of the grain and stover samples from each treatment were ground into powder for determination of $\mathrm{N}$. Nitrogen uptake in grain and stover was calculated using Equation (2). 
Table 2. Properties of soil alone and amended soil at the start of the long rain season experiments.

\begin{tabular}{|c|c|c|c|c|c|c|c|c|c|c|c|}
\hline \multirow[t]{2}{*}{ Treatments } & \multirow[t]{2}{*}{$\mathrm{pH}$} & Ammonium & Nitrate & Bacteria & Fungi & \multirow{2}{*}{$\begin{array}{c}\text { Total N } \\
(\%)\end{array}$} & \multirow{2}{*}{$\begin{array}{c}\text { Available } P \\
\text { (ppm) }\end{array}$} & \multicolumn{3}{|c|}{$\begin{array}{l}\text { Exchange Cations } \\
\quad\left(\mathrm{cmol} \mathrm{kg}^{-1}\right)\end{array}$} & \multirow[t]{2}{*}{ Ammonium/Nitrate Ratio } \\
\hline & & \multicolumn{2}{|c|}{$\left(\mathrm{mg} \mathrm{kg}^{-1}\right)$} & \multicolumn{2}{|c|}{ CFU g ${ }^{-1}$} & & & $\mathbf{K}$ & $\mathrm{Ca}$ & $\mathrm{Mg}$ & \\
\hline Soil alone & 6.2 & 1.44 & 0.36 & $2.08 \times 10^{7}$ & $3.71 \times 10^{7}$ & 0.02 & 12.0 & 1.2 & 0.77 & 0.07 & 4.0 \\
\hline Soil + BSFFF & 8.2 & 402.2 & 7.5 & $2.78 \times 10^{8}$ & $8.59 \times 10^{7}$ & 0.56 & 693.6 & 3.2 & 0.58 & 0.24 & 53.6 \\
\hline Soil + SAFI & 5.5 & 171.5 & 197.2 & $6.69 \times 10^{7}$ & $5.05 \times 10^{7}$ & 0.09 & 331.6 & 9.1 & 0.73 & 0.09 & 0.87 \\
\hline
\end{tabular}

Key: CFU, colony forming units; BSFFF, black soldier fly frass fertilizer; SAFI, commercial organic fertilizer. 


\subsubsection{Soil Sampling and Incubation}

From each plot, soil was collected from $0-20 \mathrm{~cm}$ depth before application of organic fertilizers. The soil was manually sorted to remove objects, stones, and clods bigger than $2 \mathrm{~mm}$. The soil was then homogenized by hand mixing in a basin. The two organic fertilizers were mixed with the soil at the same rate $\left(5 \mathrm{tha}^{-1}\right)$ as mentioned above and the moisture content of the mixture (soil-organic fertilizer) was adjusted to $60 \%$ soil water holding capacity. Then, two hundred grams of the mixture were placed in an air permeable ziplock bag that was sealed to prevent water entry. The bags were, then, buried at $10-20 \mathrm{~cm}$ depth in respective plots in the field. At the same time, $200 \mathrm{~g}$ of unamended soil from each plot (as control) were placed in ziplock bags and buried at the same depths $(10-20 \mathrm{~cm})$ in each of the respective plots.

Five bags were randomly buried per replicate, giving a total of 15 bags per treatment at the beginning of each cropping season. The bags were retrieved at $0,35,70,91$, and 126 days of incubation which corresponded to planting, early vegetative, tasseling, silking, and harvesting stages of the maize crop. The positions of the bags were marked using pegs to avoid disturbance during weeding and for easy retrieval. On each sampling date, the retrieved bags were labelled, placed in airtight polythene bags, and carried in a cool box containing ice blocks to reduce microbial activities during transportation. The samples were used for determination of mineral $\mathrm{N}$ content. At the same time, soil samples were also collected from the topsoil $(0-20 \mathrm{~cm})$ and subsoil $(20-40 \mathrm{~cm})$ layers of the respective plots for the determination of mineral $\mathrm{N}$ content during crop growth. A soil auger was used to collect subsamples from eight spots within the inner four rows of each plot. The subsamples were homogenized by using a quarter sampling approach to obtain representative samples. The soil samples were also placed in airtight polythene bags and carried to the laboratory using cool boxes containing ice blocks to reduce microbial activities during transportation.

\subsubsection{Mineral Nitrogen Release}

The mineral $\mathrm{N}$ released from soil alone and from soil amended with organic fertilizers at each sampling time during mineralization was determined and calculated on a per hectare basis $\left(\mathrm{kg} \mathrm{N} \mathrm{ha}^{-1}\right)$ by using the bulk density of soil and Equations (3) and (4) [23]. The $\mathrm{N}$ release rate $\left(\mathrm{kg} \mathrm{N}\right.$ ha day $\left.{ }^{-1}\right)$ was calculated by dividing mineral $\mathrm{N}$ released at each sampling date by the number of incubation days [44]:

$$
\begin{aligned}
& \text { Mineral } N \text { released }\left(\mathrm{kg} \mathrm{N} \mathrm{ha}^{-1}\right)_{\text {soil alone }}=\text { Mineral } N_{t+k \text { soil }}-\text { Mineral } N_{t i \text { soil }} \\
& \text { Mineral } N \text { released }\left(\mathrm{kg} \mathrm{N} \mathrm{ha}^{-1}\right)_{\text {amended soil }}=\text { Mineral } N_{t+k \text { amended soil }}-\text { Mineral } N_{\text {ti amended soil }}
\end{aligned}
$$

where $t_{i}$ represents sampling times $i=0,1,2,3, \ldots, t+k$ is $t_{i}$ plus time $k$ intervals where $k=1,2,3,4, \ldots$.

\subsubsection{Synchrony of Nitrogen Release and Nitrogen Uptake}

To determine the $\mathrm{N}$ synchrony, $\mathrm{N}$ flux was calculated as the difference between plant $\mathrm{N}$ uptake and mineral $\mathrm{N}$ released from the amended soils per day (Equation (5)) according to Musyoka et al. [23]. A positive $\mathrm{N}$ flux meant that the $\mathrm{N}$ released was larger than the crop's $\mathrm{N}$ demand, whereas a negative $\mathrm{N}$ flux meant that mineral $\mathrm{N}$ released was insufficient to meet the crop's $\mathrm{N}$ demand.

$$
N \text { flux }\left(k g N \text { ha day }{ }^{-1}\right)=\text { Mineral } N \text { released }_{\text {inputs }}\left(k g N \text { ha day }{ }^{-1}\right)-\text { Daily } N \text { uptake }\left(k g N \text { ha day }{ }^{-1}\right)
$$

where,

$$
\text { Daily } N \text { uptake }\left(k_{g} \text { ha day }{ }^{-1}\right)=\frac{\left(\text { N uptake }_{i+k}-N \text { uptake } t_{i}\right) k_{g} h a^{-1}}{\left(t_{i+k}-t_{i}\right)}
$$

$N$ uptake represents the quantity of $N$ taken up at each crop stage (Equation (2)). 


\subsection{Laboratory Analysis Methods}

The $\mathrm{pH}$ and electrical conductivity (EC) were determined using extracts of 1:10 and 1:2.5 (w/v) for organic fertilizer to distilled water and soil to distilled water, respectively. The contents were then shaken for $1 \mathrm{~h}$, at 180 revolutions $\mathrm{min}^{-1}$, on an orbital and linear shaker (MI0103002, Foure's scientific, Guangdong, China). Then, the $\mathrm{pH}$ and EC were read directly using a pH (AD1000, Adwa, Bucharest, Romania) and EC meter (AVI, Labtech, Mumbai, India), respectively [36].

The mineral $\mathrm{N}$ (nitrate and ammonium) was extracted from organic fertilizers and soil using $0.5 \mathrm{M}$ potassium sulphate at a ratio of $1: 10(w / v)$. The nitrate and ammonium concentrations in solutions after filtration were determined by colorimetric methods at 419 and $655 \mathrm{~nm}$, respectively, as described by Okalebo et al. [36]. The mineral $\mathrm{N}$ contents were expressed in $\mathrm{kg} \mathrm{ha}^{-1}$ using bulk density of soil at each depth and sampling period. Total organic carbon of organic fertilizers and soil was determined using the wet oxidation method [45].

The total N, P, K, Ca, and Mg of organic fertilizers were extracted using acid digestion [36]. From this extract, total N, P, and $\mathrm{K}$ were determined using the Kjeldahl digestion and distillation method [46], UV-Vis spectrometry [36], and flame photometry [36], respectively. The total Ca and Mg concentrations were determined using atomic absorption spectrometry (AAS) [36] at 422.7 and $285.2 \mathrm{~nm}$, respectively (iCE 3300 AA system, Thermo Scientific, Shanghai, China). Available P and exchangeable $\mathrm{Ca}$ and $\mathrm{Mg}$ in soil were determined using Bray 2 and AAS, respectively, whereas exchangeable $\mathrm{K}$ was determined using flame photometry. Total $\mathrm{N}$ in soil was determined using Kjeldahl digestion and distillation method, and soil texture was determined using the Bouyoucos hydrometer method [36].

\subsection{Data Analysis}

Prior to statistical analysis, data were tested for normality using the Shapiro-Wilk test. Analysis of variance tests were performed on mineral $\mathrm{N}$ content, $\mathrm{N}$ release, and $\mathrm{N}$ uptake data using a linear mixed-effect model with "lmer" function from the package "lme4" in R statistical software [47]. Fertilizer treatments and sampling time were kept as fixed effects, whereas replication was a random effect. Data on grain and stover yields were analyzed using one-way analysis of variance test. Computation of least squares means was done using "lsmeans" package, followed by mean separation using adjusted Tukey's method implemented using "cld" function from the "multicompView" package. Data was analyzed separately for each experiment and season. All the statistical analyses were conducted using R software version 3.6.0 [48].

\section{Results}

\subsection{Influence of BSFFF and SAFI Organic Fertilizer on Soil N Mineralization at Different Seasons}

The different organic fertilizer inputs caused significant differences in the quantity of mineral $\mathrm{N}$ released during the cropping seasons (short rains season $p<0.05$ and long rain season $p<0.01$ ) (Figure 2a,b). Mineral $\mathrm{N}$ released from soil amended with BSFFF reached peak levels after 70 days of incubation (coinciding with the tasseling stage) in both seasons, after which it decreased until the 125th day of incubation (coinciding with the maturity stage). For SAFI organic fertilizer, the peak levels in mineral $\mathrm{N}$ release were attained at 91 days of incubation which coincided with silking stage of maize crop during the short rain season, while in the long rain season, the $\mathrm{N}$ release kept a decreasing trend throughout the season. 


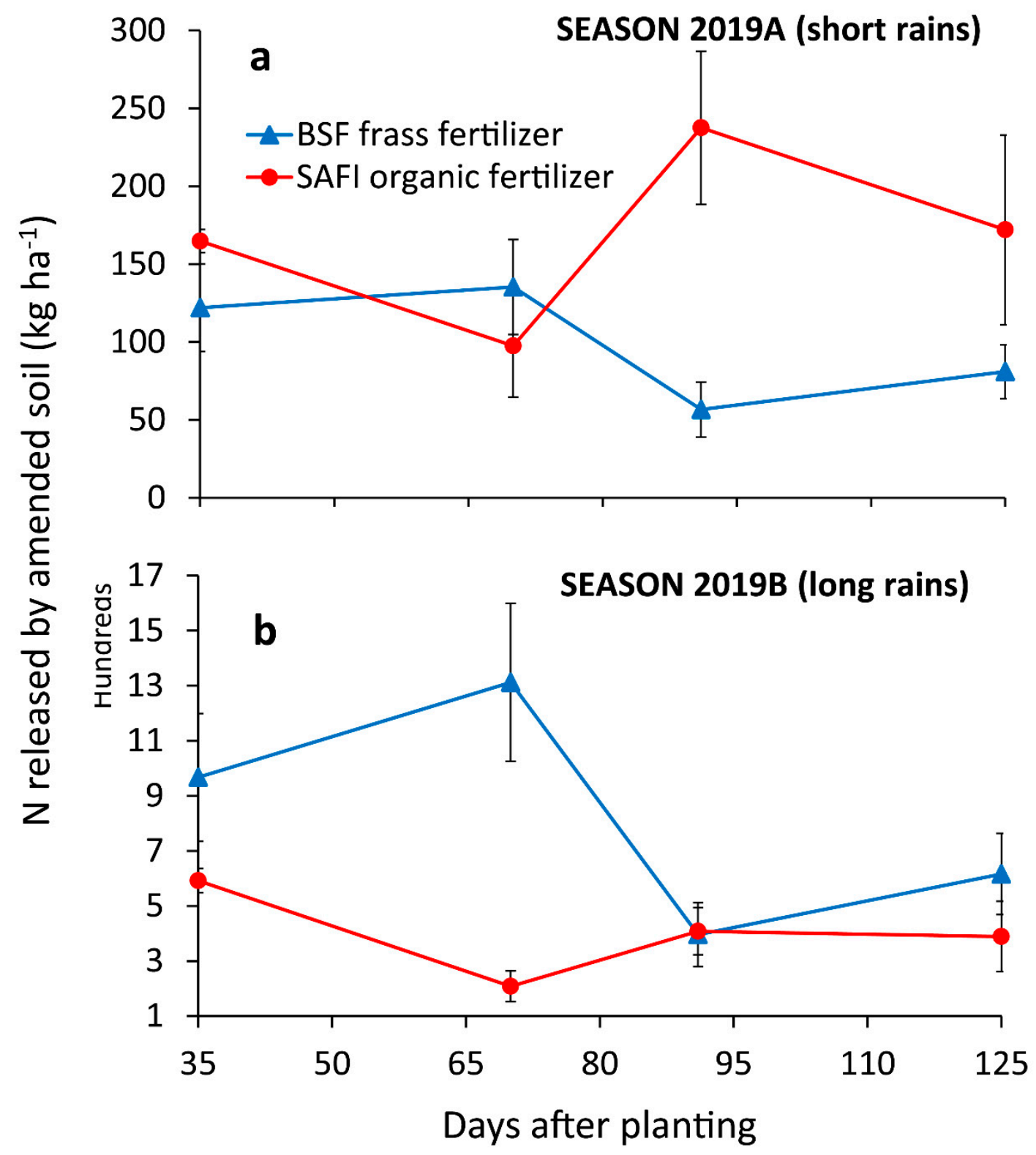

Figure 2. Nitrogen released by soil amended with black soldier fly (BSF) frass fertilizer and SAFI organic fertilizer during the short (a) and long rain (b) cropping seasons.

The soils amended with SAFI organic fertilizer released significantly $(p<0.05)$ higher mineral N at tasseling and at maturity stages than BSFFF amended soils during the short rain season. On the contrary, the mineral $\mathrm{N}$ released from soil amended with BSFFF was significantly $(p<0.01)$ higher than that released from soil amended with SAFI organic fertilizer, at the early vegetative and tasseling stages during the long rain season.

\subsection{Variation of Soil Mineral N in Two Cropping Seasons in Plots Treated with BSFFF and SAFI Organic Fertilizer}

The mineral $\mathrm{N}$ content in the topsoil $(0-20 \mathrm{~cm})$ varied significantly at different stages of maize growth during the short rain season $(p<0.05)$ (Figure $3 \mathrm{a}, \mathrm{b})$. The mineral $\mathrm{N}$ content ranged from 3 to $29 \mathrm{~kg} \mathrm{~N} \mathrm{ha}^{-1}$ at early vegetative stage, after which the amount decreased until the end of the season. Soil amended with BSFFF maintained significantly $(p<0.05)$ higher mineral $N$ content during the short rain season than that amended with SAFI organic fertilizer. During the long rain season, the mineral $\mathrm{N}$ 
amount increased to peak levels at the tasseling stage, with higher values recorded in BSFFF treated soils than those treated with SAFI.
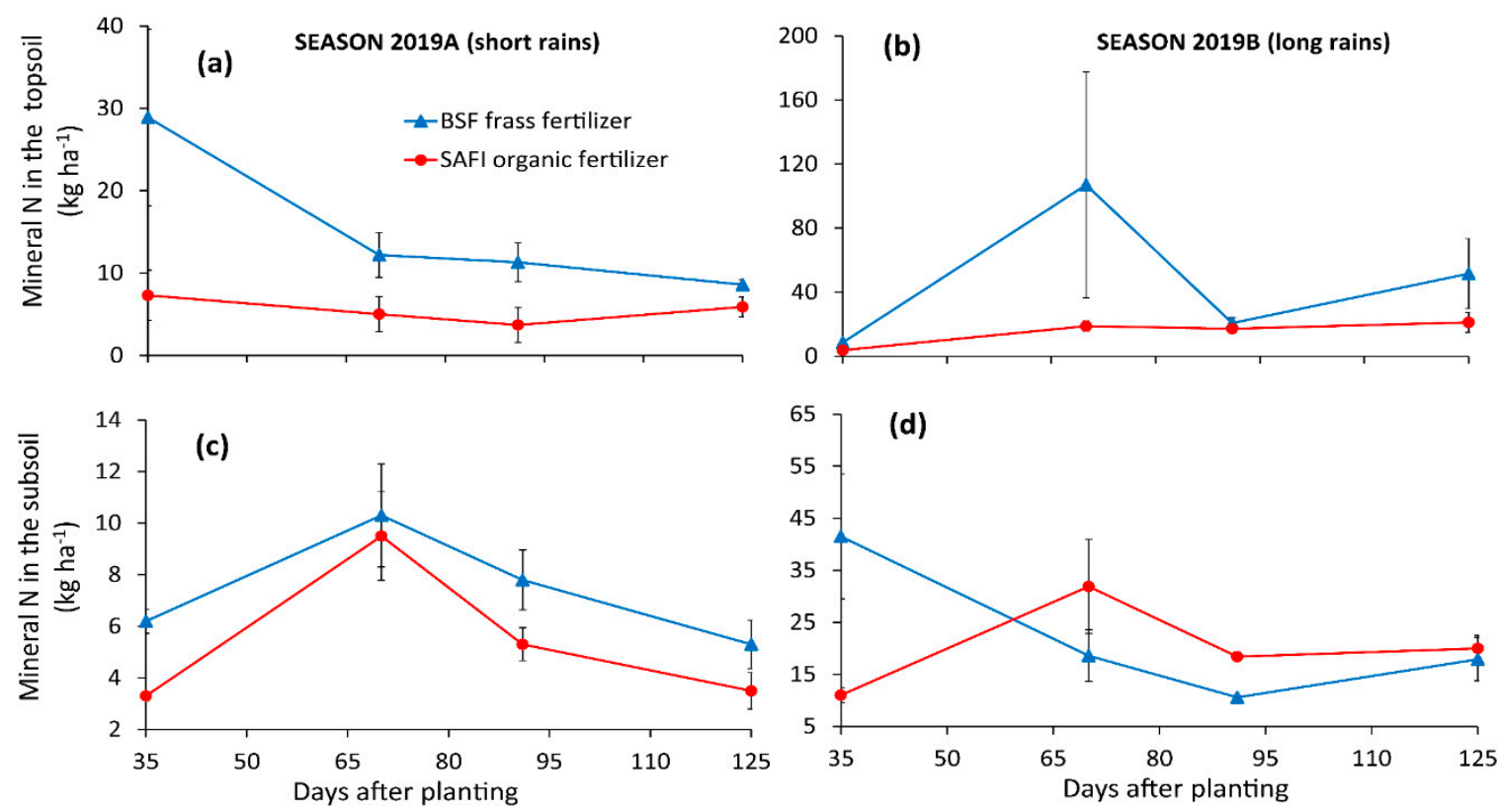

Figure 3. Mineral nitrogen content in the topsoil $(0-20 \mathrm{~cm})(\mathbf{a}, \mathbf{b})$ and subsoil $(20-40 \mathrm{~cm})(\mathbf{c}, \mathbf{d})$ layers following application of BSF frass and SAFI organic fertilizers during the short and long rain season experiments.

Similarly, in the subsoil $(20-40 \mathrm{~cm})$, the organic fertilizer amendments also caused significant differences in mineral $\mathrm{N}$ content at different maize growth stages during the short $(p<0.001)$ and long $(p<0.001)$ rain seasons (Figure 3c,d). At the early vegetative stage (35 DAP), the mineral N content was between 3 and $42 \mathrm{~kg} \mathrm{~N}$ ha $^{-1}$ but increased to peak levels $\left(9-32 \mathrm{~kg} \mathrm{~N}^{-1}\right)$ at the silking stage. From thereafter, the mineral $\mathrm{N}$ decreased until the end of the experiments. However, the mineral $\mathrm{N}$ content of soil amended with BSFFF decreased throughout the long rain season.

Soil amended with BSFFF attained significantly $(p<0.001)$ higher mineral $\mathrm{N}$ content than that treated with SAFI organic fertilizer, at the early vegetative stages of both seasons, and the silking and harvesting stages during the short rain season. At the same time, the mineral $\mathrm{N}$ content in soil amended with SAFI organic fertilizer increased beyond that of soil amended with BSFFF from the tasseling stage of the long rain season, with significant $(p<0.001)$ values observed at the silking stage.

\subsection{The Effects of BSFFF and SAFI Organic Fertilizer on Maize N Uptake}

There were significant differences in $\mathrm{N}$ uptake by maize grown in soil amended with organic inputs during the short $(p<0.001)$ and long rain $(p<0.001)$ seasons (Figure $4 \mathrm{a}, \mathrm{b})$. The $\mathrm{N}$ uptake increased significantly to peak levels (82-139 $\left.\mathrm{kg} \mathrm{N} \mathrm{ha}^{-1}\right)$ at the tasseling and silking stages, after which they decreased up to the harvesting stage. Maize grown in soil amended with BSFFF, accumulated significantly $(p<0.001)$ higher $\mathrm{N}$ levels at the silking stage of both seasons, but only at the harvesting stage during the short rain season. 

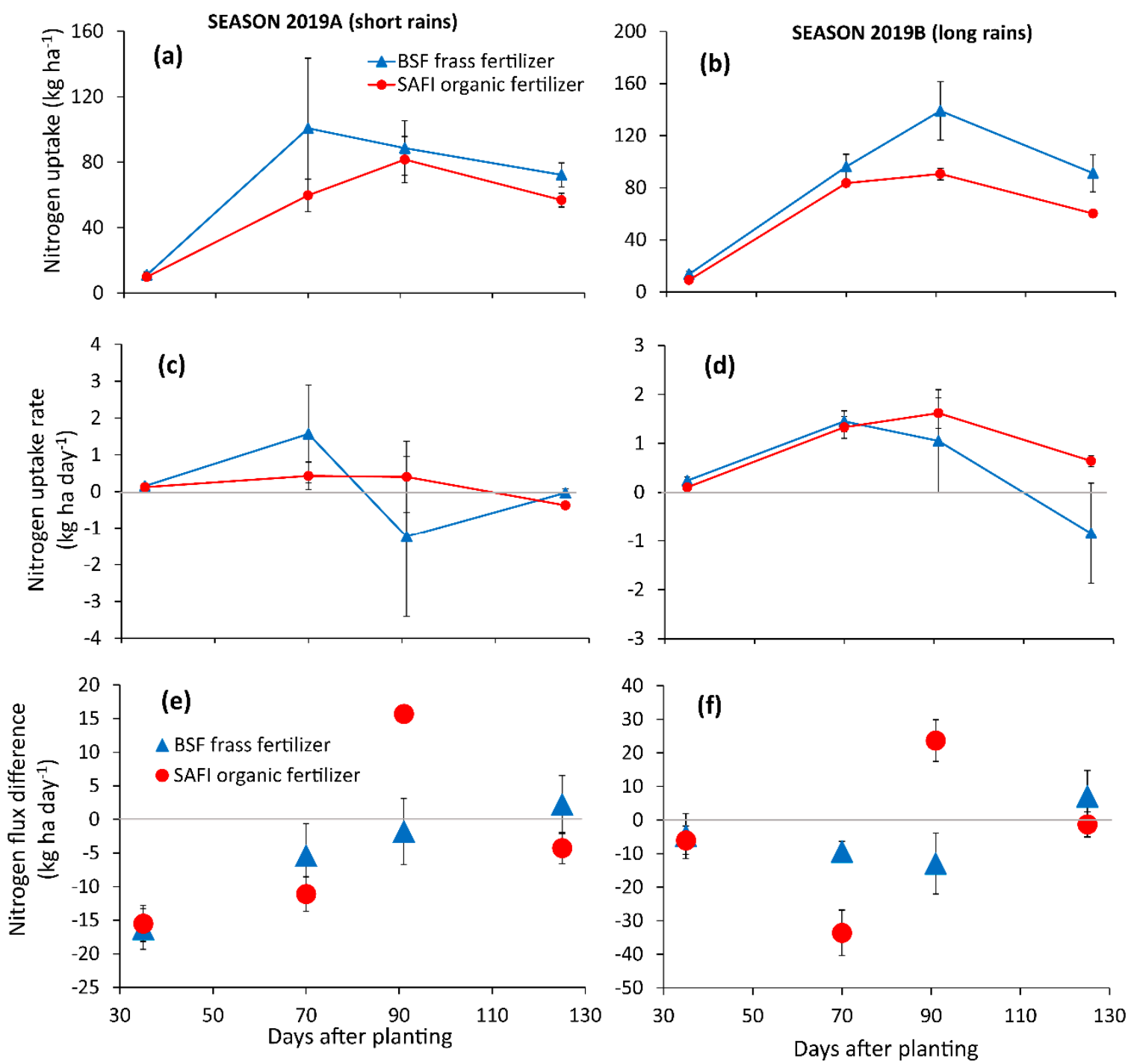

Figure 4. Effect of BSF frass and SAFI organic fertilizers on maize nitrogen uptake $(\mathbf{a}, \mathbf{b})$, nitrogen uptake rate $(\mathbf{c}, \mathbf{d})$ and nitrogen flux differences $(\mathbf{e}, \mathbf{f})$ during the short and long rain season.

The $\mathrm{N}$ uptake rates also varied significantly $(p<0.01)$ at different growth stages during the long rain season only (Figure $4 \mathrm{c}, \mathrm{d}$ ). The trends in $\mathrm{N}$ uptake rates followed those of $\mathrm{N}$ uptake, with peak values between 0.4 and $1.6 \mathrm{~kg} \mathrm{~N}$ ha day ${ }^{-1}$. The $\mathrm{N}$ uptake rate of maize grown in soil amended with BSFFF decreased to negative values $\left(-1.2 \mathrm{~kg} \mathrm{~N}\right.$ ha day $\left.{ }^{-1}\right)$ at the silking stage of the short rain season and the harvesting stages of both seasons. However, maize grown in soil amended with SAFI organic fertilizer had positive $\mathrm{N}$ uptake rates at all stages of growth, except at the harvesting stage of the short rain season, when uptake rates of $-0.4 \mathrm{~kg} \mathrm{~N}$ ha day ${ }^{-1}$ were recorded.

\subsection{Effects of BSFFF and SAFI Organic Fertilizer on the Degree of N Synchrony}

The different organic fertilizers showed significant variations in $\mathrm{N}$ flux differences during the short $(p<0.01)$ and long rain $(p<0.001)$ seasons (Figure $4 \mathrm{e}, \mathrm{f})$. Nitrogen fluxes for maize grown on soil amended with BSFFF ranged from -16 and $7 \mathrm{~kg}$ ha day ${ }^{-1}$, whereas those of SAFI organic fertilizer treatments ranged from -34 and $24 \mathrm{~kg} \mathrm{~N}$ ha day ${ }^{-1}$. The $\mathrm{N}$ fluxes for BSFFF amended treatments increased from the early vegetative stage during the short rain season towards positive values but decreased with higher negative values up to the silking stage during the long rain season.

Positive $\mathrm{N}$ flux differences for soil amended with BSFFF were attained at the harvesting stages of both seasons. However, positive $\mathrm{N}$ flux differences for soil amended with SAFI organic fertilizer 
were achieved at the silking stage in both seasons. Higher positive $\mathrm{N}$ flux differences were recorded during the long rain season as compared with the short rain season. Soil amended with SAFI organic fertilizer produced significantly $(p<0.001)$ higher positive $\mathrm{N}$ flux differences than that amended with BSFFF, in both seasons.

\subsection{Effects of BSFFF and SAFI Organic Fertilizer on Maize Grain Yield}

The different organic fertilizer amendments applied at various $\mathrm{N}$ rates caused significant differences in maize grain yields during the short $(p<0.05)$ and long rain $(p<0.001)$ season experiments (Table 3$)$. Maize grain yields increased with an increase in $\mathrm{N}$ rates and all treatments producing higher grain yields during the long rain season than in the short rain season. On the one hand, the BSFFF treatments achieved higher maize grain yields than the equivalent rates of SAFI organic fertilizer. However, maize grain yields did not vary significantly among the different BSFFF treatments. On the other hand, plots treated with $100 \mathrm{~kg} \mathrm{~N} \mathrm{ha}^{-1}$ supplied as SAFI organic fertilizer produced significantly $(p<0.001)$ higher maize grain yield during the long rain season than where $30 \mathrm{~kg} \mathrm{~N} \mathrm{ha}^{-1}$ of the same fertilizer were applied.

Table 3. Maize grain yield and nitrogen fertilizer replacement values of BSF frass and SAFI organic fertilizers.

\begin{tabular}{|c|c|c|c|c|c|}
\hline \multirow[b]{2}{*}{ Fertilizer } & \multirow{2}{*}{$\begin{array}{c}\text { Rate } \\
\left(\mathrm{kg} \mathrm{N} \mathrm{ha}^{-1}\right)\end{array}$} & \multicolumn{2}{|c|}{ Season 2019A (Short Rains) } & \multicolumn{2}{|c|}{ Season 2019B (Long Rains) } \\
\hline & & $\begin{array}{l}\text { Grain Yield } \\
\quad\left(\mathrm{t} \mathrm{ha}^{-1}\right)\end{array}$ & NFRV (\%) & $\begin{array}{l}\text { Grain Yield } \\
\quad\left(\mathrm{t} \mathrm{ha}^{-1}\right)\end{array}$ & NFRV (\%) \\
\hline \multirow{3}{*}{ BSFFF } & 30 & $4.96 \pm 0.21 \mathrm{a}$ & $229.4 \pm 28.4 \mathrm{a}$ & $5.20 \pm 0.32 \mathrm{ab}$ & $131.8 \pm 34.3 \mathrm{ab}$ \\
\hline & 60 & $5.59 \pm 0.40 \mathrm{a}$ & $165.9 \pm 32.7 \mathrm{ab}$ & $5.95 \pm 0.26 \mathrm{a}$ & $151.0 \pm 37.5 \mathrm{a}$ \\
\hline & 100 & $5.72 \pm 0.32 \mathrm{a}$ & $105.3 \pm 17.7 \mathrm{ab}$ & $6.15 \pm 0.10 a$ & $110.6 \pm 8.6 \mathrm{ab}$ \\
\hline \multirow{4}{*}{ SAFI } & 30 & $4.49 \pm 0.52 \mathrm{a}$ & $178.6 \pm 59.7 \mathrm{ab}$ & $3.68 \pm 0.04 c$ & $3.5 \pm 1.3 \mathrm{c}$ \\
\hline & 60 & $4.00 \pm 0.44 \mathrm{a}$ & $61.2 \pm 21.9 \mathrm{~b}$ & $4.48 \pm 0.27 b c$ & $30.4 \pm 10.9 \mathrm{bc}$ \\
\hline & 100 & $4.51 \pm 0.15 \mathrm{a}$ & $52.1 \pm 5.3 b$ & $5.12 \pm 0.20 \mathrm{ab}$ & $35.6 \pm 6.5 \mathrm{bc}$ \\
\hline & $p$ value & * & * & $* * *$ & ** \\
\hline
\end{tabular}

Maize grown in soil amended with 30 and $60 \mathrm{~kg} \mathrm{~N} \mathrm{ha}^{-1}$ supplied as BSFFF produced significantly $(p<0.001)$ higher grain yields than equivalent rates of SAFI organic fertilizer during the long rain season. Plots treated with $100 \mathrm{~kg} \mathrm{~N}$ ha $^{-1}$ supplied as BSFFF produced the highest maize grain yields, which were 27 and $20 \%$ higher than those produced by equivalent rates of SAFI organic fertilizer during the short and long rain season, respectively.

\subsection{Nitrogen Fertilizer Equivalence Values of BSFFF and SAFI Organic Fertilizer}

The $\mathrm{N}$ fertilizer equivalence (NFE) values of organic fertilizers applied at different $\mathrm{N}$ rates varied significantly during the short $(p<0.05)$ and long rain $(p<0.01)$ seasons (Table 3$)$. At equivalent $\mathrm{N}$ rates, BSFFF achieved higher NFE than SAFI organic fertilizer. During the short rain season, the NFE of BSFFF applied at $30 \mathrm{~kg} \mathrm{~N} \mathrm{ha}^{-1}$ was 3.8 and 4.4 times higher $(p<0.05)$ than that of SAFI organic fertilizer applied at 60 and $100 \mathrm{~kg} \mathrm{~N}$ ha $^{-1}$, respectively. Likewise, the NFE of BSFFF applied at $60 \mathrm{~kg} \mathrm{~N} \mathrm{ha}^{-1}$ was significantly $(p<0.01)$ higher than those of all SAFI organic fertilizer treatments, and two to five times greater than the NFE of SAFI organic fertilizer applied at an equivalent rate.

The NFE of BSFFF treatments decreased with an increase in $\mathrm{N}$ application rates, with the highest values observed at the rate of $30 \mathrm{~kg} \mathrm{~N} \mathrm{ha}^{-1}$. Increasing the $\mathrm{N}$ rate of BSFFF to $100 \mathrm{~kg} \mathrm{~N} \mathrm{ha}^{-1}$ decreased the NFE by 2.2 and 1.2 times during the short and long rain seasons, respectively. However, NFE of 
SAFI organic fertilizer did not follow a consistent trend, whereby, it decreased with an increase in $\mathrm{N}$ rates during the short rain season but varied proportionally with $\mathrm{N}$ rates during the long rain season.

\section{Discussion}

\subsection{Effects of BSFFF and SAFI Organic Fertilizer on the Degree of N Synchrony}

The net $\mathrm{N}$ immobilization observed at the active stages of maize growth (Figure $3 \mathrm{c}, \mathrm{d}$ ) has been previously reported $[23,26,44]$ and could be largely attributed to the quality of organic inputs applied (Table 1). Fertilizers generated from insect frass contain high levels of labile organic carbon and organically bound ammonium nitrogen $[17,28,49,50]$, which requires time to be converted into a plant available form $\left(\mathrm{NO}_{3}{ }^{-}\right)$through the nitrification process. At the same time, ammonium nitrogen is a highly preferred soil microorganisms making it prone to immobilization and denitrification pathways. Our results are consistent with those of $\mathrm{Li}$ and $\mathrm{Li} \mathrm{[24]} \mathrm{who} \mathrm{established} \mathrm{that} \mathrm{ammonium} \mathrm{nitrogen} \mathrm{is}$ one of the major $\mathrm{N}$ fractions that influences the quantity of $\mathrm{N}$ released from organic fertilizers. Due to the high demand for available $\mathrm{N}$ by microorganisms, there was a high possibility that most of the ammonium $\mathrm{N}$ from BSFFF underwent rapid immobilization after soil application [44,51], thereby, denying $\mathrm{N}$ supply to the plant at the early growth stages. Furthermore, some ammonium could have also been lost through denitrification and volatilization especially in soils with $\mathrm{pH}$ values (>7.5) (Table 2) and high temperature [52], thus reducing the quantity of available $\mathrm{N}$ for plant uptake at the early stages of maize growth.

Biochar consists of recalcitrant organic carbon that is resistant to microbial decomposition and, consequently, causes delays in $\mathrm{N}$ release $[53,54]$. Biochar consists of compounds such as lignin and polyphenols [55] which have been reported to cause $\mathrm{N}$ immobilization [23,33]. Low total $\mathrm{N}$ content, such as that observed in SAFI amended soils (Table 2), has also been reported to stimulate $\mathrm{N}$ immobilization [56], thereby, reducing the quantity of available N. Furthermore, the low ammonium/nitrate ratio (0.43) and high nitrate concentration associated with SAFI organic fertilizer (Table 2) could have facilitated $\mathrm{N}$ leaching, especially during the long rain season, when moisture content was high [44]. High nitrate leaching $(80 \%$ of total $\mathrm{N})$, up to $1 \mathrm{~m}$ down the soil profile, has been reporting in maize cropping systems of Kenya [57] and could be attributed to the high sand content and low organic matter levels of our experimental soil (Table 1).

It was noted that BSFFF treatments had less negative $\mathrm{N}$ fluxes at the tasseling stage, whereas soil amended with SAFI organic fertilizer achieved positive $\mathrm{N}$ flux differences earlier (silking stage) than where BSFFF was applied (maturity stage) (Figure 4e,f). The negative $\mathrm{N}$ fluxes observed during the active growth stages could be attributed to $\mathrm{N}$ immobilization and leaching, as explained above. Previous research efforts have suggested supplementation with mineral $\mathrm{N}[23,26,58]$ or application of organic fertilizers before planting [24] to compensate for $\mathrm{N}$ immobilization during the early growth stages and periods of peak $\mathrm{N}$ demand. On the one hand, the present study established that an application of $2-16 \mathrm{~kg} \mathrm{ha}^{-1}$ of mineral $\mathrm{N}$ at periods between the early vegetative and silking stages (35-91 days after planting) was necessary to compensate for the deficits in $\mathrm{N}$ release observed, while using the BSF frass fertilizer for maize production. On the other hand, $6-36 \mathrm{~kg} \mathrm{~N} \mathrm{ha}^{-1}$ of mineral $\mathrm{N}$ fertilizer would be required between the early vegetative and tasseling stages (35-70 days after planting) to cause $\mathrm{N}$ synchrony for maize growth, while using SAFI organic fertilizer. However, it is expected that with continued organic fertilizer application, mineral $\mathrm{N}$ release is expected to gradually increase and consequently reduce the period of $\mathrm{N}$ immobilization.

Conversely, the positive $\mathrm{N}$ flux difference observed at the silking stage (91 DAP) (Figure 4e,f) associated with SAFI organic fertilizer amendment could be explained by the increase in mineral $\mathrm{N}$ release (Figure 2a,b) at 91 days of incubation. Such excesses in $\mathrm{N}$ could have resulted into $\mathrm{N}$ leaching to deeper subsoil layers [57]. However, the higher $\mathrm{N}$ uptake achieved by maize grown on soil amended with BSFFF as compared with SAFI organic fertilizer (Figure $4 a, b$ ) could be partly attributed to the higher mineral $\mathrm{N}$ content in topsoil (Figure $3 \mathrm{a}, \mathrm{b}$ ). It was also noted that peak $\mathrm{N}$ uptake by maize 
grown on soil amended with BSFFF did not coincide with periods of positive $\mathrm{N}$ fluxes, indicating asynchrony. This mismatch has been previously attributed to $\mathrm{N}$ uptake from deeper soil layers or acquisition from $\mathrm{N}$ rich microsites in soil $[23,44]$. Deeper plant root growth and spread due to the presence of plant growth promoting organisms and growth hormones, such as auxin and gibberellins, have been reported, while using insect frass as a biofertilizer [59]. Such behavior of root growth could have been crucial in nutrient acquisition by maize grown using BSFFF. In addition, the higher $\mathrm{N}$ release and uptake in the second season (long rain season) could be attributed to residual effect of inputs applied in the first season and higher rainfall during the long rain season $[23,53]$.

\subsection{Nitrogen Fertilizer Equivalence Values of BSFFF and SAFI Organic Fertilizer}

The higher grain yields associated with BSFFF at all N rates (Table 3) indicate the high quality of this fertilizer as compared with the commercial organic fertilizer, SAFI. Our results are supported by previous studies which have reported improved drought tolerance, disease suppression, and higher crop growth yield, while using insect frass fertilizer $[49,50,59]$. Furthermore, the chitin contained in BSF frass fertilizers has been reported to improve plant health by stimulating disease resistance in crops [60]. Such additional benefits provided by BSF frass fertilizer could have been responsible for the higher grain yields achieved from maize grown in soil amended with this fertilizer. The minimal and nonsignificant increase in grain yields at rates beyond $30 \mathrm{~kg} \mathrm{~N} \mathrm{ha}^{-1}$ (Table 3), suggests that the low rate of BSFF fertilizer $\left(30 \mathrm{~kg} \mathrm{~N} \mathrm{ha}^{-1}\right)$ is enough for maize production. However, economic studies are required to assess whether the increases in grain yield obtained at rates higher than $30 \mathrm{~kg} \mathrm{~N} \mathrm{ha}^{-1}$ were profitable.

The significantly higher nitrogen fertilizer equivalence values of BSFFF applied at 30 and $60 \mathrm{~kg} \mathrm{~N} \mathrm{ha}^{-1}$ as compared with all SAFI organic fertilizer treatments during the short and long rain seasons (Table 3), respectively, indicate the high quality of BSFFF. The SAFI organic fertilizer is made of biochar and organic inputs with high recalcitrant carbon which are associated with $\mathrm{N}$ immobilization [23]. Furthermore, the SAFI organic fertilizer has a high nitrate concentration, that could have been lost through leaching especially during the long rain season [57]. The nitrogen fertilizer equivalence values (105-229\%) of BSFFF obtained in this study are comparable to those obtained by Kimetu et al. [33], while using tithonia as organic fertilizer, but higher than those reported for calliandra and senna during the same study. Furthermore, the nitrogen fertilizer equivalence values of BSFFF reported, in the present study, are higher than those previously reported for Lucerne [61], poultry litter and yard waste compost [22], as well as slurry from cattle [31,58,61], and pigs [41]. On the contrary, the low and inconsistent nitrogen fertilizer equivalence recorded from SAFI organic fertilizer could be improved by combining it with a mineral $\mathrm{N}$ fertilizer to increase the $\mathrm{N}$ supply [23].

Contrary to previous studies where nitrogen fertilizer equivalence values of different organic amendments were found to increase with an increase in $\mathrm{N}$ rates [32], this study established that the nitrogen fertilizer equivalence values of BSFFF decreased with an increase in $\mathrm{N}$ application rates. The high value of nitrogen fertilizer equivalence obtained at low $\mathrm{N}$ rates implies that even at low application rates, the BSFFF can perform equally well or even better than the mineral $\mathrm{N}$ fertilizer and highlights its high quality as an organic fertilizer input [60]. Findings from the present study are crucial in changing attitudes towards organic fertilizer use, with the advantage of less bulkiness and high nutrient quality. Subsequently, the heavy reliance on the highly expensive mineral $\mathrm{N}$ fertilizers could be lessened by adopting high-quality organic fertilizers such as BSFFF.

\section{Conclusions}

The findings of this study show that $\mathrm{N}$ release from both the BSFFF and SAFI organic fertilizers during the early crop growth stages was slow which led to insufficient $\mathrm{N}$ synchrony at periods of peak $\mathrm{N}$ demand. Nevertheless, soil amended with BSFFF had more mineral $\mathrm{N}$ in the topsoil which resulted in higher $\mathrm{N}$ uptake and grain yield than the soil amended with SAFI, the commercial organic fertilizer. This means that inorganic $\mathrm{N}$ supplementation could be necessary to compensate for $\mathrm{N}$ immobilization 
observed at the early growth stages. The high grain yields and nitrogen fertilizer equivalence values associated with BSFFF indicate great potential for improving crop productivity. Future studies would be necessary to determine the $\mathrm{N}$ accumulated in root biomass and $\mathrm{N}$ associated with microbes to be able to accurately estimate $\mathrm{N}$ fluxes in soils amended with BSFFF.

Author Contributions: Conceptualization, D.B., B.M., N.K., D.N., K.K.M.F., F.M.K., M.W.M., S.S., S.E., and C.M.T.; Methodology, D.B., B.M., N.K., K.K.M.F., M.W.M., and C.M.T.; Software, D.B., B.M., N.K., M.W.M., and C.M.T.; Validation, D.B., B.M., N.K., K.K.M.F., M.W.M., T.D., and C.M.T.; Formal analysis, D.B., B.M., N.K., K.K.M.F., M.W.M., T.D., and C.M.T.; Investigation, D.B., B.M., N.K., D.N., K.K.M.F., M.W.M., and C.M.T.; Resources, B.M., N.K., M.W.M., S.E., and C.M.T.; Data curation, B.M., N.K., M.W.M., and C.M.T.; Writing-original draft preparation, D.B., B.M., N.K., M.W.M., and C.M.T.; Writing-review and editing, D.B., B.M., N.K., D.N., K.K.M.F., F.M.K., M.W.M., T.D., and C.M.T.; Visualization, D.B., B.M., N.K., M.W.M., and C.M.T.; Supervision, B.M., N.K., D.N., K.K.M.F., M.W.M., and C.M.T.; Project administration, B.M., N.K., D.N., M.W.M., S.S., T.D., S.E., and C.M.T.; Funding acquisition, K.K.M.F., D.N., M.W.M., S.S., T.D., S.E., and C.M.T. All authors have read and agreed to the published version of the manuscript.

Funding: This research was financially supported by the Canadian International Development Research Centre (IDRC) and the Australian Centre for International Agricultural Research (ACIAR) (INSFEED-Phase 2: Cultivate Grant No: 108866-001), the Netherlands Organization for Scientific Research, the WOTRO Science for Global Development (NWO-WOTRO) (ILIPA-W 08.250.202), and The Rockefeller Foundation (SiPFeed-2018 FOD 009) through the International Centre of Insect Physiology and Ecology (ICIPE). We also gratefully acknowledge the ICIPE core funding provided by United Kingdom's Foreign, Commonwealth \& Development Office (FCDO); the Swedish International Development Cooperation Agency (Sida); the Swiss Agency for Development and Cooperation (SDC); the Federal Democratic Republic of Ethiopia; and the Government of the Republic of Kenya. The views expressed herein do not necessarily reflect the official opinion of the donors. The senior author, Dennis Beesigamukama, was financially supported by a German Academic Exchange Service (DAAD) In-Region Postgraduate Scholarship.

Acknowledgments: We remain indebted to Faith N. Wamurango, Shem Ondiaka, Isiah E. Rachami, Joshua Wambua, Mathew K. Theuri, and Kennedy K. Kiprotich for their substantial contribution during the data collection process of the study.

Conflicts of Interest: The authors declare no conflict of interest.

\section{References}

1. Vanlauwe, B.; Coyne, D.; Gockowski, J.; Hauser, S.; Huising, J.; Masso, C.; Nziguheba, G.; Schut, M.; Van Asten, P. Sustainable intensification and the African smallholder farmer. Curr. Opin. Environ. Sustain. 2014, 8, 15-22. [CrossRef]

2. Vanlauwe, B.; Descheemaeker, K.; Giller, K.E.; Huising, J.; Merckx, R.; Nziguheba, G.; Wendt, J. Integrated soil fertility management in sub-Saharan Africa: Unravelling local adaptation. Soil J. 2015, 1, 491-508. [CrossRef]

3. Cobo, J.G.; Dercon, G.; Cadisch, G. Nutrient balances in African land use systems across different spatial scales: A review of approaches, challenges and progress. Agric. Ecosyst. Environ. 2010, 136, 1-15. [CrossRef]

4. Tully, K.; Sullivan, C.; Weil, R.; Sanchez, P. The State of Soil Segradation in Sub-Saharan Africa: Baselines, Trajectories, and Solutions. Sustainability 2015, 6523-6552. [CrossRef]

5. Musinguzi, P.; Ebanyat, P.; Tenywa, J.S.; Basamba, T.A.; Tenywa, M.M.; Mubiru, D.N. Critical soil organic carbon range for optimal crop response to mineral Fertiliser nitrogen on a Ferralsol. Exp. Agric. 2016, 52, 635-653. [CrossRef]

6. Grigatti, M.; Boanini, E.; Cavani, L.; Ciavatta, C.; Marzadori, C. Phosphorus in Digestate-Based Compost: Chemical Speciation and Plant-Availability. Waste Biomass Valorization 2015, 6, 481-493. [CrossRef]

7. Baligar, V.C.; Fageria, N.K.; He, Z.L. Nutrient Use Efficiency in Plants. Commun. Soil Sci. Plant Anal. 2001, 32, 921-950. [CrossRef]

8. Ch'Ng, H.Y.; Ahmed, O.H.; Majid, N.M.A. Improving phosphorus availability, nutrient uptake and dry matter production of Zea Mays L. on a tropical acid soil using poultry manure biochar and pineapple leaves compost. Exp. Agric. 2016, 52, 447-465. [CrossRef]

9. Tittonell, P.; Vanlauwe, B.; Corbeels, M.; Giller, K.E. Yield gaps, nutrient use efficiencies and response to fertilisers by maize across heterogeneous smallholder farms of western Kenya. Plant Soil 2008, 313, $19-37$. [CrossRef] 
10. Wortmann, C.S.; Kaizzi, K.C.; Maman, N.; Cyamweshi, A.; Dicko, M.; Garba, M.; Milner, M.; Senkoro, C.; Tarfa, B.; Tettah, F.; et al. Diagnosis of crop secondary and micro-nutrient deficiencies in sub-Saharan Africa. Nutr. Cycl. Agroecosyst. 2019, 113, 127-140. [CrossRef]

11. FAO. The State of Food and Agriculture. Leveraging food systems for inclusive rural transformation. Available online: www.fao.org/publications (accessed on 17 October 2017).

12. Rufino, M.C.; Dury, J.; Tittonell, P.; van Wijk, M.T.; Herrero, M.; Zingore, S.; Mapfumo, P.; Giller, K.E. Competing use of organic resources, village-level interactions between farm types and climate variability in a communal area of NE Zimbabwe. Agric. Syst. 2011, 104, 175-190. [CrossRef]

13. Rusinamhodzi, L.; Corbeels, M.; Giller, K.E. Diversity in crop residue management across an intensification gradient in southern Africa: System dynamics and crop productivity. Field Crop. Res. 2016, 185, 79-88. [CrossRef]

14. Ndambi, O.A.; Pelster, D.E.; Owino, J.O.; de Buisonjé, F.; Vellinga, T. Manure Management Practices and Policies in Sub-Saharan Africa: Implications on Manure Quality as a Fertilizer. Front. Sustain. Food Syst. 2019, 3, 1-14. [CrossRef]

15. Makkar, H.P.S.; Tran, G.; Heuzé, V.; Ankers, P. State-of-the-art on use of insects as animal feed. Anim. Feed Sci. Technol. 2014, 197, 1-33. [CrossRef]

16. Oonincx, D.G.A.B.; Van Broekhoven, S.; Van Huis, A.; Van Loon, J.J.A. Feed conversion, survival and development, and composition of four insect species on diets composed of food by-products. PLoS ONE 2015, 10, 1-20. [CrossRef] [PubMed]

17. Lalander, C.H.; Fidjeland, J.; Diener, S.; Eriksson, S.; Vinnerås, B. High waste-to-biomass conversion and efficient Salmonella spp. reduction using black soldier fly for waste recycling. Agron. Sustain. Dev. 2015, 35, 261-271. [CrossRef]

18. Oonincx, D.G.A.B.; van Huis, A.; van Loon, J.J.A. Nutrient utilisation by black soldier flies fed with chicken, pig, or cow manure. J. Insects Food Feed 2015, 1, 131-139. [CrossRef]

19. Xiao, X.; Mazza, L.; Yu, Y.; Cai, M.; Zheng, L.; Tomberlin, J.K.; Yu, J.; van Huis, A.; Yu, Z.; Fasulo, S.; et al. Efficient co-conversion process of chicken manure into protein feed and organic fertilizer by Hermetia illucens L. (Diptera: Stratiomyidae) larvae and functional bacteria. J. Environ. Manag. 2018, 217, 668-676. [CrossRef]

20. Diener, S.; Studt Solano, N.M.; Roa Gutiérrez, F.; Zurbrügg, C.; Tockner, K. Biological treatment of municipal organic waste using black soldier fly larvae. Waste Biomass Valorization 2011, 2, 357-363. [CrossRef]

21. Cabrera, M.L.; Kissel, D.E.; Vigil, M.F. Nitrogen Mineralization from Organic Residues. J. Environ. Qual. 2005, 34, 75-79. [CrossRef]

22. Bowden, C.; Spargo, J.; Evanylo, G. Mineralization and N fertilizer equivalent value of composts as assessed by tall fescue (festuca arundinacea). Compost. Sci. Util. 2007, 15, 111-118. [CrossRef]

23. Musyoka, M.W.; Adamtey, N.; Bünemann, E.K.; Muriuki, A.W.; Karanja, E.N.; Mucheru-Muna, M.; Fiaboe, K.K.M.; Cadisch, G. Nitrogen release and synchrony in organic and conventional farming systems of the Central Highlands of Kenya. Nutr. Cycl. Agroecosyst. 2019, 113, 283-305. [CrossRef]

24. Li, L.; Li, S. Nitrogen mineralization from animal manures and its relation to organic $\mathrm{N}$ fractions. J. Integr. Agric. 2014, 13, 2040-2048. [CrossRef]

25. Cai, A.; Xu, H.; Shao, X.; Zhu, P.; Zhang, W.; Xu, M.; Murphy, D.V. Carbon and nitrogen mineralization in relation to soil particle-size fractions after 32 years of chemical and manure application in a continuous maize cropping system. PLoS ONE 2016, 11, 1-14. [CrossRef] [PubMed]

26. Johnson, H.J.; Colquhoun, J.B.; Bussan, A.J.; Laboski, C.A.M. Estimating nitrogen mineralization of composted poultry manure, organic fertilizers, and green manure crops for organic sweet corn production on a sandy soil under laboratory conditions. Horttechnology 2012, 22, 37-43. [CrossRef]

27. Alizadeh, P.; Fallah, S.; Raiesi, F. Potential N mineralization and availability to irrigated maize in a calcareous soil amended with organic manures and urea under field conditions. Int. J. Plant Prod. 2012, 6, 493-512.

28. Adin Yéton, B.G.; Aliou, S.; Noël, O.; Guillaume Lucien, A.; Attanda Mouinou, I.; Victor Attuquaye, C.; Christophe Achille Armand Mahussi, C.; Marc, K.; Guy Apollinaire, M. Decomposition and nutrient release pattern of agro-processing by-products biodegraded by fly larvae in Acrisols. Arch. Agron. Soil Sci. 2019, 00, 1-12. [CrossRef]

29. Friedel, J.K.; Herrmann, A.; Kleber, M. Ion exchange resin-soil mixtures as a tool in net nitrogen mineralisation studies. Soil Biol. Biochem. 2000, 32, 1529-1536. [CrossRef] 
30. Osterholz, W.R.; Rinot, O.; Liebman, M.; Castellano, M.J. Can mineralization of soil organic nitrogen meet maize nitrogen demand? Plant Soil 2017, 415, 73-84. [CrossRef]

31. Lalor, S.T.J.; Schröder, J.J.; Lantinga, E.A.; Oenema, O.; Kirwan, L.; Schulte, R.P.O. Nitrogen Fertilizer Replacement Value of Cattle Slurry in Grassland as Affected by Method and Timing of Application. J. Environ. Qual. 2011, 40, 362-373. [CrossRef]

32. Hijbeek, R.; ten Berge, H.F.M.; Whitmore, A.P.; Barkusky, D.; Schröder, J.J.; van Ittersum, M.K. Nitrogen fertiliser replacement values for organic amendments appear to increase with $\mathrm{N}$ application rates. Nutr. Cycl. Agroecosyst. 2018, 110, 105-115. [CrossRef]

33. Kimetu, J.M.; Mugendi, D.N.; Palm, C.A.; Mutuo, P.K.; Gachengo, C.N.; Bationo, A.; Nandwa, S.; Kungu, J.B. Nitrogen fertilizer equivalencies of organics of differing quality and optimum combination with inorganic nitrogen source in Central Kenya. Nutr. Cycl. Agroecosyst. 2004, 68, 127-135. [CrossRef]

34. Kenya Meteorological Department. Kenya Weather. Available online: https://www.govserv.org/KE/Dagoretti/ 246433692156497/Kenya-Meteorological-Department (accessed on 12 February 2019).

35. Gachene, C.; Kimaru, G. Soil Fertility and Land Productivity: A Guide for Extension Workers in the Eastern Africa Region; World Agroforestry: Nairobi, Kenya, 2003; ISBN 9966896651.

36. Okalebo, J.R.; Gathua, K.W.; Woomer, P.L. Laboratory Methods of Soil and Plant Analysis: A Working Manual, 2nd ed.; TSBF-CIAT and SACRED Africa: Nairobi, Kenya, 2002.

37. Shumo, M.; Osuga, I.M.; Khamis, F.M.; Tanga, C.M.; Fiaboe, K.K.M.; Subramanian, S.; Ekesi, S.; van Huis, A.; Borgemeister, $\mathrm{C}$. The nutritive value of black soldier fly larvae reared on common organic waste streams in Kenya. Sci. Rep. 2019, 9, 1-13. [CrossRef] [PubMed]

38. Safi Organics. Decentralizing Fertilizer Production. Available online: https://safiorganics.co.ke/ (accessed on 5 August 2018).

39. Tittonell, P.; Corbeels, M.; Van Wijk, M.T.; Vanlauwe, B.; Giller, K.E. Combining organic and mineral fertilizers for integrated soil fertility management in smallholder farming systems of Kenya: Explorations using the crop-soil model FIELD. Agron. J. 2008, 100, 1511-1526. [CrossRef]

40. Murwira, H.K.; Mutuo, P.; Nhamo, N.; Marandu, A.E.; Rabeson, R.; Mwale, M.; Palm, C.A. Fertilizer Equivalency Values of Organic Materials of Differing Quality. In Intergrated Plant Nutrient Management in sub-Saharan Africa: From Concept to Practice; CABI: Wallingford, UK, 2003; p. 367.

41. Van Middelkoop, J.C.; Holshof, G. Nitrogen Fertilizer Replacement Value of Concentrated Liquid Fraction of Separated Pig Slurry Applied to Grassland. Commun. Soil Sci. Plant Anal. 2017, 48, 1132-1144. [CrossRef]

42. Mucheru-Muna, M.; Mugendi, D.; Pypers, P.; Mugwe, J.; Kung'U, J.; Vanlauwe, B.; Merckx, R. Enhancing maize productivity and profitability using organic inputs and mineral fertilizer in central Kenya small-hold farms. Exp. Agric. 2014, 50, 250-269. [CrossRef]

43. Musyoka, M.W.; Adamtey, N.; Muriuki, A.W.; Cadisch, G. Effect of organic and conventional farming systems on nitrogen use efficiency of potato, maize and vegetables in the Central highlands of Kenya. Eur. J. Agron. 2017, 86, 24-36. [CrossRef]

44. Loecke, T.D.; Cambardella, C.A.; Liebman, M. Synchrony of net nitrogen mineralization and maize nitrogen uptake following applications of composted and fresh swine manure in the Midwest U.S. Nutr. Cycl. Agroecosyst. 2012, 93, 65-74. [CrossRef]

45. Nelson, D.W.; Sommers, L.E. Total carbon, organic carbon, and organic matter. Methods of soil analysis Part 2: Chemical and microbiological properties. Am. Soc. Agron. 1982, 9, 539-579.

46. Jackson, M.L. Soil Chemical Analysis; Prentice Hall of India Pvt. Ltd.: New Delhi, India, 1973; p. 498.

47. Bates, D.; Mächler, M.; Bolker, B.M.; Walker, S.C. Fitting linear mixed-effects models using lme4. J. Stat. Softw. 2015, 67. [CrossRef]

48. R Core Team R. A Language and Environment for Statistical Computing. Vienna, Austria. Available online: http://www.r-project.org/ (accessed on 15 June 2019).

49. Kagata, H.; Ohgushi, T. Positive and negative impacts of insect frass quality on soil nitrogen availability and plant growth. Popul. Ecol. 2012, 54, 75-82. [CrossRef]

50. Houben, D.; Daoulas, G.; Faucon, M.P.; Dulaurent, A.M. Potential use of mealworm frass as a fertilizer: Impact on crop growth and soil properties. Sci. Rep. 2020, 10, 1-9. [CrossRef]

51. Fornara, D.A.; Bardgett, R.; Steinbeiss, S.; Zak, D.R.; Gleixner, G.; Tilman, D. Plant effects on soil N mineralization are mediated by the composition of multiple soil organic fractions. Ecol. Res. 2011, 26, 201-208. [CrossRef] 
52. Bernal, M.P.; Alburquerque, J.A.; Moral, R. Composting of animal manures and chemical criteria for compost maturity assessment. A review. Bioresour. Technol. 2009, 100, 5444-5453. [CrossRef]

53. Rovira, P.; Vallejo, V.R. Labile and recalcitrant pools of carbon and nitrogen in organic matter decomposing at different depths in soil: An acid hydrolysis approach. Geoderma 2002, 107, 109-141. [CrossRef]

54. Kleber, M. What is recalcitrant soil organic matter? Environ. Chem. 2010, 7, 320-332. [CrossRef]

55. Sanchez-Monedero, M.A.; Cayuela, M.L.; Roig, A.; Jindo, K.; Mondini, C.; Bolan, N. Role of biochar as an additive in organic waste composting. Bioresour. Technol. 2018, 247, 1155-1164. [CrossRef] [PubMed]

56. Gómez-Muñoz, B.; Hinojosa, M.B.; García-Ruiz, R. In situ net N mineralisation and nitrification under organic and conventionally managed olive oil orchards. Nutr. Cycl. Agroecosyst. 2015, 101, 223-239. [CrossRef]

57. Musyoka, M.W.; Adamtey, N.; Muriuki, A.W.; Bautze, D.; Karanja, E.N.; Mucheru-Muna, M.; Fiaboe, K.K.M.; Cadisch, G. Nitrogen leaching losses and balances in conventional and organic farming systems in Kenya. Nutr. Cycl. Agroecosyst. 2019, 114, 237-260. [CrossRef]

58. Cavalli, D.; Cabassi, G.; Borrelli, L.; Geromel, G.; Bechini, L.; Degano, L.; Marino Gallina, P. Nitrogen fertilizer replacement value of undigested liquid cattle manure and digestates. Eur. J. Agron. 2016, 73, 34-41. [CrossRef]

59. Poveda, J.; Jiménez-Gómez, A.; Saati-Santamaría, Z.; Usategui-Martín, R.; Rivas, R.; García-Fraile, P. Mealworm frass as a potential biofertilizer and abiotic stress tolerance-inductor in plants. Appl. Soil Ecol. 2019, 142, 110-122. [CrossRef]

60. Quilliam, R.S.; Nuku-Adeku, C.; Maquart, P.; Little, D.; Newton, R.; Murray, F. Integrating insect frass biofertilisers into sustainable peri-urban agro-food systems. J. Insects Food Feed 2020, 6, 315-322. [CrossRef]

61. De Notaris, C.; Sørensen, P.; Møller, H.B.; Wahid, R.; Eriksen, J. Nitrogen fertilizer replacement value of digestates from three green manures. Nutr. Cycl. Agroecosyst. 2018, 112, 355-368. [CrossRef]

(C) 2020 by the authors. Licensee MDPI, Basel, Switzerland. This article is an open access article distributed under the terms and conditions of the Creative Commons Attribution (CC BY) license (http://creativecommons.org/licenses/by/4.0/). 